\title{
Major Fungi Diseases of Cashew Trees (Anacardium occidental L.) in Cameroon
}

\author{
Jules Patrice Ngoh Dooh ${ }^{1}$, Christine Baba Djoumba Asta ${ }^{1}$, Bouba Djile ${ }^{2}$, Dany Brice Tsouala Tchoupou ${ }^{3}$, \\ Alain $\mathrm{Heu}^{4}$, Serge Bertrand Mboussi ${ }^{5}$, William Norbert Tueguem Kuate ${ }^{6} \&$ Zachee Ambang $^{7}$ \\ ${ }^{1}$ Department of Biological Sciences, Faculty of Science, University of Maroua, Maroua, Cameroon \\ ${ }^{2}$ Department of Plants genetic and Biotechnology, Institute of Agricultural Research for Development of \\ Maroua, Maroua, Cameroon \\ ${ }^{3}$ Higher National Polytechnic School of Maroua, University of Maroua, Maroua, Cameroon \\ ${ }^{4}$ Higher Technical Teacher's Training College, Department of Agriculture and Agropastoral, Ebolowa, \\ Cameroon \\ ${ }^{5}$ Laboratory of Plant Biology, University of Douala, Douala, Cameroon \\ ${ }^{6}$ Laboratory of Biotechnologies, Phytopathology and Microbiology Unit, University of Yaounde I, Yaounde, \\ Cameroon \\ Correspondence: Jules Patrice Ngoh Dooh, Department of Biological Sciences, Faculty of Science, University of \\ Maroua, P.O. Box 814, Maroua, Cameroon. Tel: (237)-699-219-391. E-mail: ndjuliopat@yahoo.fr
}

Received: December 31, 2020

Accepted: February 1, 2021

Online Published: February 15, 2021

doi:10.5539/jas.v13n3p124

URL: https://doi.org/10.5539/jas.v13n3p124

\begin{abstract}
The culture of cashew (Anacardium occidentale L.) is increasing in the Far North Cameroon. But, the productivity is threatened by the development of diseases in orchads. Therefore, the aim of this study is to identify diseases and pathogens involved in cashew cultivation. The diseases were identified under the basis of the identification keys. The fungal structures were characterized using an optical microscope and the pathogenicity test were carried out. Incidence, severity and prevalence of diseases were assessed in the dry season and the rainy season. Seven diseases and seven pathogens have been identified: anthracnose (Colletotrichum gloeosporioides Penz), pestalotia leaf spot (Pestalotia heterocornis), alternaria (Alternaria solani), drying of buds (Colletotrichum gloeosporioides, Phomopsus anacardii and Curvularia lunata), dieback (Colletotrichum sp. and Lasiodiplodia sp.), blight of leaves (Pestalotia heterocornis and Colletotrichum gloeosporioides) and powdery mildew (Oidium anacardii Noack). Whatever the season; anthracnose, pestalotia leaf spot an drying of buds are diseases with higher incidence (more than 85,60 and $75 \%$ respectively) and higher prevalence. The severity of the diseases varied according to the location and season. Pathogenicity test revealed that all the test fungi were pathogenic to their respective host parts except cashew powder mildew and alternaria. The results of this study represent database for implementation of integrated disease management approaches in Cameroon.
\end{abstract}

Keywords: Anacardium occidentale, diseases, fungi, pathogenicity, incidence, severity

\section{Introduction}

In most developing countries, agriculture employs $70 \%$ of the workforce and provides between 20 and $60 \%$ of gross domestic product (GDP), and contributes between 10 and 90\% of exportation of goods (Didier, 2001).

In the three northern regions of Cameroon, Adamawa, the North and the Far North, cotton is, and remains, the only cash crop. Thus in 1975, the Cameroonian state introduced cashews in the northern region to fight against deforestation by distributing seeds to local populations. Some farmers in the North and Far North region have started to cultivate cashew for its broad ecological spectrum and to associate it with vegetable and food crops (Noiha et al., 2017).

In Far North Cameroon, many projects are underway in the far north to expand cashew production. However, many orchards associated with mango trees belong to rural cultivators. Cashew production represents a new source of income for the rural population (Adeniyi et al., 2019; Noiha et al., 2017; Diaz et al., 2003). 
Some farmers in the North and Far North region have started to cultivate cashew for its great ecological aspect and to associate it with vegetable and food crops (Djongmo, 2016). The poverty rate in the Far North is $74.3 \%$ while the national average is $34.5 \%$ (INS, 2015). The occupation of unemployed young people from the Far North to cultivate the cashew tree could greatly reduce the poverty rate in this part of the country.

The cashew tree is very exported for its cashew nuts whose almond, rich in phenol, oil and sugars, is used in the food industry (Lautié et al., 2001). It is also cultivated for the apple (cashew apple) which contains a sweet, acidic and astringent juice. This apple is directly edible when ripe or then transformed into juice, wine, syrup or beer in Burkina Faso, Senegal and Ivory Coast.

However, many threats are found in différent orchads of this crop, such as pests and diseases, which in many cases are limiting their commercial exploitation (Assenga et al., 2020; Viana et al., 2007). In fact, despite pests, more than twelve diseases ares described on cashew in some countries (Mozambique, Benin, Brazil, Ivory Coast, Burundi and Tanzania), among which fungal diseases, such as anthracnose (Colletotrichum gloeosporioides Penz), pestalotia leaf spot (Pestalotia heterocornis) dieback (Lasiodiplodia sp.) and powdery mildew (Oidium anacardii Noack) (Wonni et al., 2017; Nakpalo et al., 2017; Khatoon et al., 2017; Monteiro et al., 2015; Afouda et al., 2013; Adeniyl et al., 2011; NARI, 2009; Cardoso et al,. 2009; Cooke, 2006; Freire et al., 2002; Grundon, 2002; Teixeira, 1988).

In Cameroon, despite of few diseases including powdery mildew and anthracnose suspected only on the basis of the symptoms described in the literature (Tandjiékpon et al., 2003; Mingue, 2019), the problem is the lack of data on the main cashew tree diseases. But, many projects are underway with the aim of expanding the production and marketing areas for cashew nuts. It is therefore necessary to have knowledge of the phytosanitary problems linked to the cashew tree. Then, this study was undertaken to find cashew fungal diseases and their pathogens in order to serve as fungal diseases management.

\section{Methods}

\subsection{Study Areas}

Samples were collected in Far North Cameroon during two years (2019 and 2020). Departments of Diamaré and Mayo Danay, which are the only cashew production areas were choosen. Three orchards were surveyed in each of the three localities of the two subdivisions choosen by site. Maroua $1^{\text {st }}\left(10.4236^{\circ} \mathrm{N}\right.$ and $10.6279^{\circ} \mathrm{N}-14.1961^{\circ} \mathrm{E}$ and $\left.14.4814^{\circ} \mathrm{E}\right)$ and Yagoua $\left(10.1159^{\circ} \mathrm{N}\right.$ and $10.4079^{\circ} \mathrm{N}-15.1679^{\circ} \mathrm{E}$ and $\left.15.3886^{\circ} \mathrm{E}\right)$. Isolation and characterization of pathogens where carry out in Biological Sciences Laboratory of Maroua and Laboratory of Biotechnologies, Phytopathology and Microbiology Unit, of University of Yaounde I.

\subsection{Plant Material}

In the differents orchads, trees of cashew were at less 10 years old. Two varieties were represented, AB05-08 variety with red fruit and $\mathrm{AB} 29$ variety with yellow fruits.

\subsection{Experimental Design and Collection of Samples}

The experimental design was completely randomized with three replications in each site. In each Department, a subdivision has been chosen (Maroua and Yagoua) representing our study sites. In each subdivision, three districts have been chosen representing the blocks (Djarengol, Palar and Meskine for Maroua; Bidim, Simakalsou and Bidim 2 for Yagoua). In each block, one (01) orchard was chosen at random representing the plots. In each plot, 20 trees of cashew were chosen for sampling and monitor the progress of the disease, about sixty (60) trees per study site.

The sampling was performed during two years (2019-2020) in the dry (From March to April) and rainy (July to August) seasons. Far North is characterized by a long dry season and a short rainy season (3 months).

In each orchards, infected samples of organs, were collected (in morning) on ten trees chosen randomly each orchard visited. For each sample, the geographical coordinates and the locality name, were noted. The samples were packaged in plastic bags containing cotton soaked with sterile distilled water and transported in laboratory. Samples were used immediately or were stored at $4{ }^{\circ} \mathrm{C}$.

\subsection{Pathogens Isolation and Characterization}

Identification of disease was done by observation of symptoms in field in differents orchads and compared to an identification keys (Nakpalo et al., 2017; Wonni et al., 2017; Afouda et al., 2013; Uaciquete, 2013; Barnett \& Hunter, 1987). 
Isolation and identification of pathogen consisting of observation, measurements and description of fungal structures in microscope. Optical microscope with micrometer was used to measure length and width of fungi conidia (Afouda et al., 2013; Uaciquete, 2013; Barnett \& Hunter, 1987).

Samples was carried out on Potato Dextrose Agar (PDA; containing $\mathrm{g} \mathrm{L}^{-1}: 200 \mathrm{~g}$ potato, $20 \mathrm{~g}$ dextrose, $15 \mathrm{~g}$ agar) and water agar (WA, containing $\mathrm{g} \mathrm{L}^{-1}, 15 \mathrm{~g}$ agar) media. Petri dishes of $90 \mathrm{~mm}$ were used.

Sections of $1 \mathrm{~cm}$ diameter were cut from leaves with symptoms using sterilized scalpel. Explants were washed in tap water. Then, sterilized in ethanol (70\%) firstly for one minute followed by immersion in $1 \%$ of sodium hypochlorite solution for $2 \mathrm{~min}$. The infected section was then washed three times in Sterile Distilled Water (SDW). Sterilized explants were dried and grown on Petri dishes containing WA and PDA medium. Cultures were incubated at $25^{\circ} \mathrm{C}$ on photoperiod $12 / 12 \mathrm{~h}$. After 3 or 7 days, colony growth was transferred on a new PDA medium to obtain pure cultures and to observed and to describe structures of pathogen.

Samples already contening conidia in field were also used to characterize and identify fungi.

\subsection{Pathogenicity Test}

The young cashew seedlings, 3-6 months old and carrying six (06) to eight (08) leaves were cleaned with tap water, alcohol at $70{ }^{\circ} \mathrm{C}$ and then with sodium hypochlorite $(1 \%)$ and rinsed with sterile distilled water. For moisture conservation, these plants were closed with transparent plastic bags until the next morning. Four plants are been inoculated for each fungus. Inoculum was prepared from 7 days old pure cultures by flooding plates with $10 \mathrm{~mL}$ sterile distilled water. Conidia were collected with $20 \mathrm{ml}$ sterile syringe. Conidia concentration was adjusted to $4-6 \times 10^{5}$ conidia/ml with haemacytometer. The conidia suspension $(12.5 \mathrm{ml}$ per plant) was applied on leaves inferior surface with a $20 \mathrm{ml}$ syringe. Control plants were sprayed with sterilised distilled water. Plants were covered with a clear plastic to maintain humidity after inoculation. Plants were regularly sprayed with water. Koch's postulate was carried out from the organs showing symptoms after infection (Nakpalo et al., 2017; Wonni et al., 2017).

\subsection{Assessment of Disease Incidence}

Diseases incidence was assessed on twenty trees selected randomly in each orchads. Modified protocol of Shomari and Kennedy (1999) and Afouda et al. (2013) was used. The evaluation was made according to the North, South, East and West sides of the crown (canopy) of each tree. 56 to 60 trees were observed by site.

Incidence was estimated following the formula:

$$
\mathrm{I}(\%)=\mathrm{n} / \mathrm{N} \times 100
$$

Where, $\mathrm{n}$ is the number of trees infected by a disease and $\mathrm{N}$, the total number of trees inspected. Data were recorded during dry (March-April) and rainy (July-August) seasons.

\subsection{Assessment of Disease Severity}

Severity was assessed by estimating the leaf area occupied by the symptoms of the disease following the formula:

$$
\mathrm{S}=\sum(\mathrm{ab}) / \mathrm{N}
$$

Where, $\mathrm{S}$ is the average severity of the disease in the site, $\sum$ is the sum of the products of the number of diseased plants, (a) the severity index, (b) the number of plants with the index given in $\%$ and $\mathrm{N}$ the number total trees observed. Data were recorded during dry (March-April) and rainy (July-August) seasons.

The disease severity index was assessed using a visual scale of 0 to 9 (Cardoso et al., 2004; Soro, 2012; Afouda et al., 2013): $0=$ no symptom; $1=1-4 \% ; 2=5-9 \% ; 3=10-19 \% ; 4=20-29 \% ; 5=30-44 \% ; 6=45-59 \% ; 7=$ $60-75 \% ; 8=76-90 \% ; 9 \geq 91 \%$ percentage of average lesion per leaf infected.

\subsection{Assessment of the Prevalence of the Disease}

The prevalence assessment was carried out on an average of 40 trees in each variety at the two study sites using the following formula:

$$
\mathrm{P}=\mathrm{n} / \mathrm{N} \times 100
$$

Where, $\mathrm{n}$ is the number of tree of the variety affected and $\mathrm{N}$ is the total number of feet of the variety in the site.

\subsection{Statistical Analysis}

Data collected were analyzed using analysis of variance (ANOVA 1) and averages were compared through Duncan multiple range test at 5\%. Statistical software SPSS 16.0 was used. 


\section{Results and Discussion}

\subsection{Diseases Inventoried}

Several diseases have been identified on the organs (leaves, inflorescences, fruits, barks, twigs and stems) of cashew in the surveyed orchards. Six diseases have been identified, anthracnose, pestaliotia leaf spot, alternaria, powdery mildew, dry buds and dieback. Anthracnose appeared in the fruit by a black spot at the top of cashew apple or nut, which then evolves over all the fruit (Figure 1d). At the leaves, symptoms are leaf spots, dark in color and in some cases orange-brown (Figures 1a and 1b). Drop of Leaves can lead to dieback. At inflorescences symptoms are abortion of flowers (Figure $1 \mathrm{j}$ ).

Pestalotia symptoms on leaves were characterized by the transparent aureoles (on upper and lower sides) which turn to necrosis (Figure 1e). Blight appeared in young leaves (Figure 1f).

Alternaria symptoms are characterized by yellow leaf spots (Figure 1g).

Symptoms of powdery mildew were several whitish mildiew colonies on the upper surfaces of leaves (Figure 1h).

Drying of the buds is characterized by young buds which dry out and eventually fall (Figure 1i). Sometimes this drying out of the buds begins at the level of the young leaves and then evolves at the level of the twigs (Figures $1 \mathrm{j}$ and $1 \mathrm{k})$.
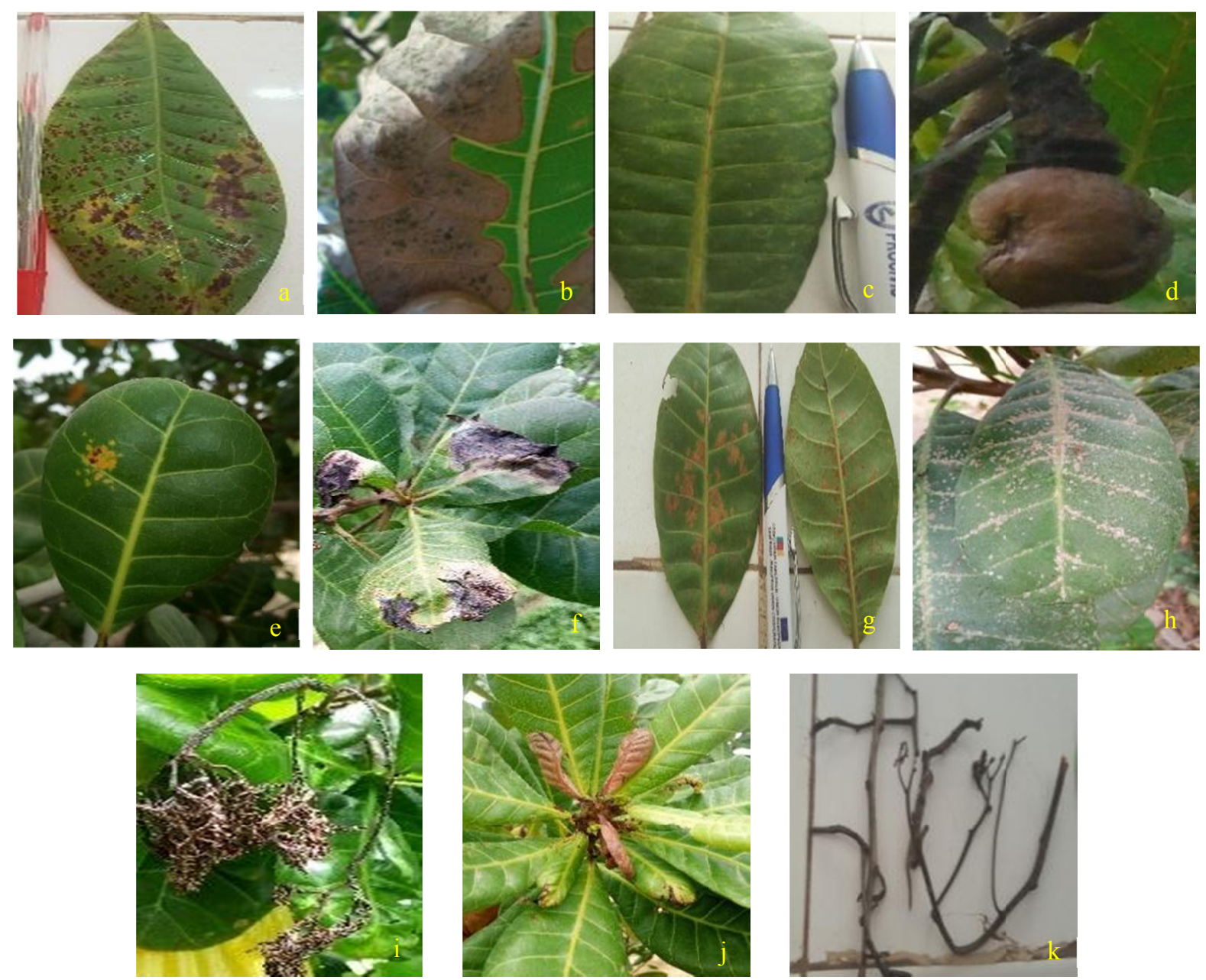

Figure 1. Different field symptoms fungal diseases of cashew in Cameroon. abcd: anthracnose symptoms; e: symptoms of pestalotia leaf spot; f: symptom of blight; g: alternaria symptoms; h: symptoms of powdery mildew; i-k: drying buds symptoms 


\subsection{Fungi Identified and Associated With Symptoms}

Seven fungi have been isolated and identified: Colletotrichum gloeosporioides (anthracnose, dry bud), Pestalotia heterocornis (Pestalotia, anthracnose), Alternaria sp. (alternaria), Phomopsus anacardii (dry buds), Curvularia lunata (dry buds) and Ö̈dium anacardii Noack. (powdery mildew), Lasiodiplodia sp. (dieback) (Figure 2).

Some agents were associated on infected organs in certain orchards. C. gloeosporioides and Pestalotia heterocornis was sometimes associated in leaves with anthracnose. C. gloeosporioides was also associated with Curvularia lunata and Phomopsus anacardii in drying of inflorescences.
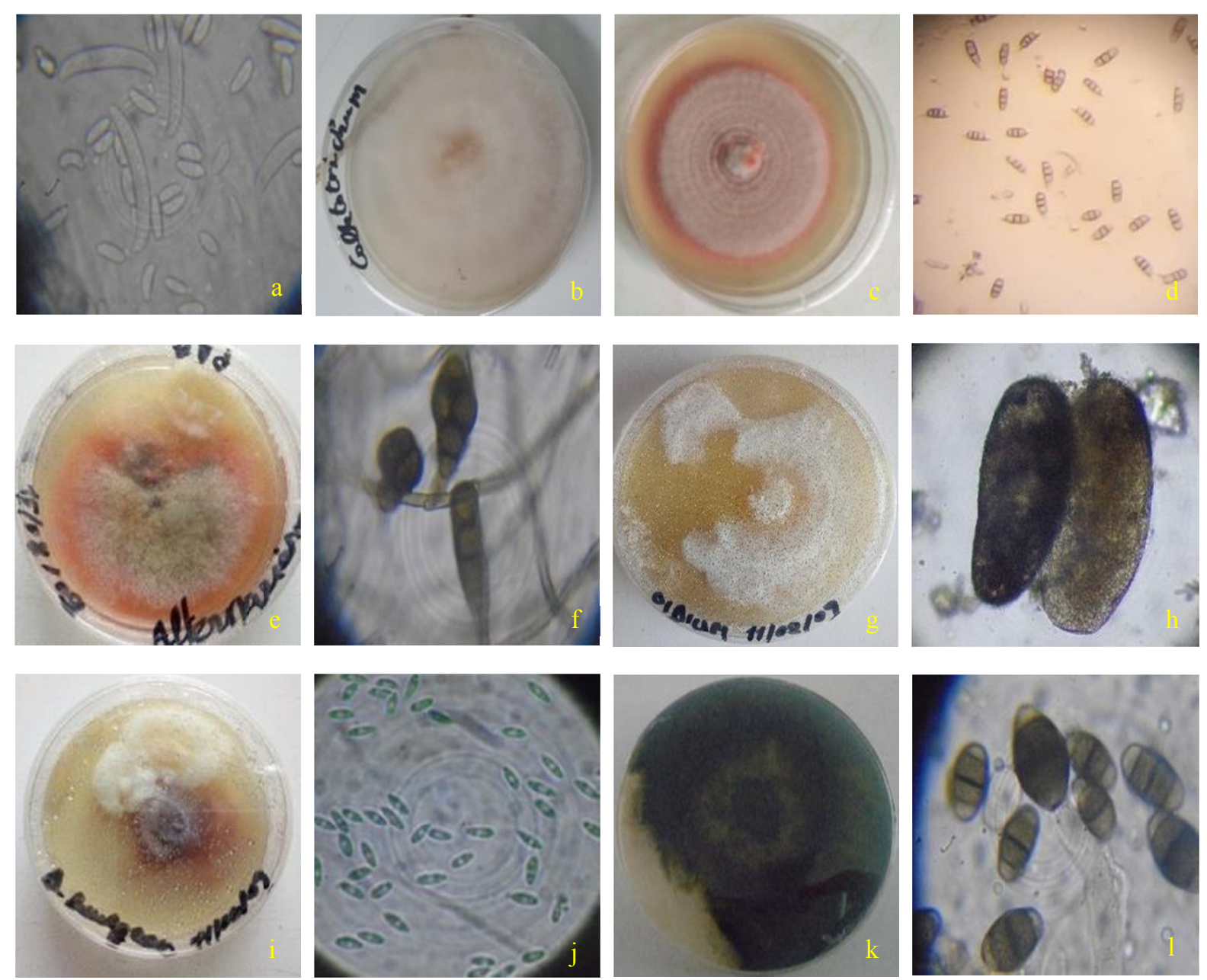

Figure 2. Fungal structures (mycelial and conidia) of differents pathogens identified in cashew in Cameroon. a: pure culture; b: conidia of C. gloeosporioides; c: pure culture; d: conidia of $P$. heterocornis; e: pure culture; f: conidia of Alternaria solani; g: pure culture; h: sporangia of Ö̈dium anacardii Noack; i: pure culture; j: conidia of Phomopsus anacardii; k: pure culture; 1: conidia of Curvularia spp.

\subsection{Conidial Characteristics}

Conidia and sporangia had cylindrical, globular and fusiform shapes. Conidial size recorded showed differences in length and width between the pathogens isolated from cashew trees. Length and width vary in each species of fungus. Curvularia lunata recorded, for these two measures, the maximum higher value, respectively 30.99 and $20.66 \mu \mathrm{m}$ for the length and width while Colletotrichum gloeosporioides showed the lowest size 18.07 and 5.16 $\mu \mathrm{m}$, respectively for length and width. The conidia of Powdery mildew anacardii Noack could not be observed. Only the sporangia were measured with a length between $289.24-330.56 \mu \mathrm{m}$ and a width of 206.6-216.93 $\mu \mathrm{m}$ (Table 1). 
Table 1. Size of conidia and sporangia $(\mu \mathrm{m})$

\begin{tabular}{llllll}
\hline \multirow{2}{*}{ Fungi characteristics } & \multicolumn{5}{c}{ Fungi species } \\
\cline { 2 - 6 } & $\begin{array}{l}\text { Colletotrichum } \\
\text { gloeosporioides }\end{array}$ & $\begin{array}{l}\text { Pestalotia } \\
\text { heterocornis }\end{array}$ & $\begin{array}{l}\text { Alternaria } \\
\text { solani }\end{array}$ & $\begin{array}{l}\text { Curvularia } \\
\text { lunata }\end{array}$ & $\begin{array}{l}\text { Ödium anacardii } \\
\text { Noack }\end{array}$ \\
\hline Length & $10.33-18.07$ & $15.49-20.66$ & $18.07-51.65$ & $20.66-30.99$ & $289.24-330.56$ \\
width & $2.58-5.16$ & $10.33-12.91$ & $5.16-20.66$ & $10.33-20.66$ & $206.6-216.93$ \\
\hline
\end{tabular}

\subsection{Pathogenicity Test}

Cashew plants inoculated with conidial suspension of selected isolates developed spot on plants, necrotic black spot (C. gloeosporioides) and brown spot ( $P$. heterocornis). All the isolates were pathogenic on cashew plants, except Oidium anacardii and $A$. solani. The control did not develop any symptom (Figure 3a) during probation period (Figure 3). The pathogen was re-isolated from infected cashew leaves on PDA to fulfil Koch's postulates. Powdery mildew and alternaria did not show similar symptoms of infected plants in field.
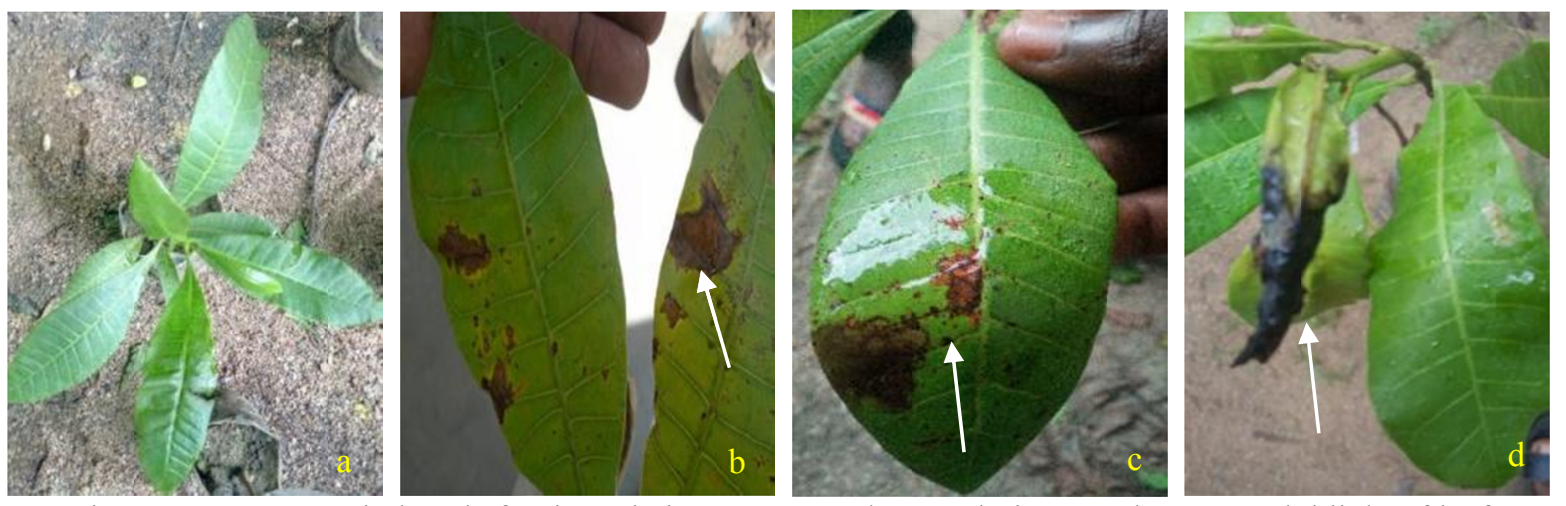

Figure 3. Symptoms induced after inoculation. a: contro; b: Pestalotia; c: anthracnose; d: blight of leaf

\subsection{Rainfall}

There was no rainfall during March and April months at the two sites. The highest precipitation was recorded in Maroua in July, August and October with more than $120 \mathrm{~mm}$ of water. The highest rainfall was recorded in August at $80 \mathrm{~mm}$ in Yagoua alone. Overall, the rainfall was higher in Maroua $(1140.2 \mathrm{~mm})$ than in Yagoua $(901 \mathrm{~mm})$ during the season (Figure 4).

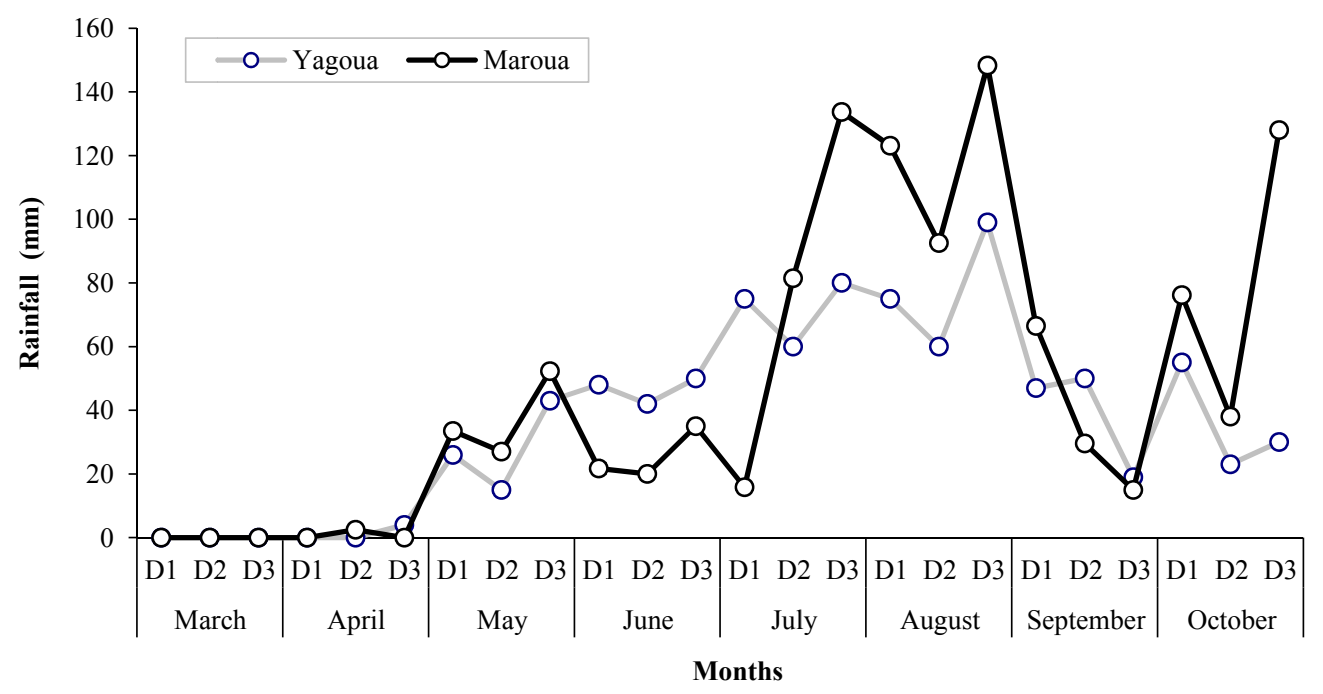

Figure 4. Evolution of rainfall during the season in the two sites 


\subsection{Average Incidence (\%) of Diseases at the Two Sites}

A significant difference was obtained for each disease according to the season and the site $(\mathrm{P}<0.05)$. In Maroua, the most common diseases are anthracnose, pestalotia leaf spot and drying out of the buds, with incidences of 74.58 and $89.58 \% ; 85.33$ and $79.16 \% ; 65$ and $79.58 \%$ in the two seasons respectively. The incidence of alternaria and powdery mildew was low in the dry season, $5 \%$ and $27 \%$ respectively. In Yagoua, the greatest incidence in the dry season was obtained with pestalotia, $96.66 \%$ (Table 2 ).

Similarly, the average incidence showed a significant difference between the different diseases $(\mathrm{P}<0.05)$. Anthracnose, pestalotia leaf spot and drying out of buds were the most common diseases at the two sites, with mean incidences of $74.37 \pm 4.2,88.62 \pm 5.1$ and $69.48 \pm 4.1 \%$, respectively. The average incidence of alternaria and powdery mildew was low (Table 2 ).

Table 2. Average incidence (\%) of diseases at the two sites

\begin{tabular}{|c|c|c|c|c|c|}
\hline \multirow{3}{*}{ Diseases } & \multicolumn{4}{|c|}{ Sites } & \multirow{3}{*}{ Mean } \\
\hline & \multicolumn{2}{|c|}{ Maroua } & \multicolumn{2}{|c|}{ Yagoua } & \\
\hline & Dry season & Rainy season & Dry season & Rainy season & \\
\hline Anthracnose & $74.58 \pm 2.1 \mathrm{a}$ & $89.58 \pm 1.4 \mathrm{~b}$ & $45 \pm 2.5 \mathrm{a}$ & $88.33 \pm 10.4 b$ & $74.37 \pm 4.2 \mathrm{C}$ \\
\hline Pestalotia leaf spot & $85.33 \pm 5.4 \mathrm{a}$ & $79.16 \pm 3.8 \mathrm{a}$ & $96.66 \pm 5.7 \mathrm{~b}$ & $63.33 \pm 5.7 \mathrm{a}$ & $88.62 \pm 5.1 \mathrm{D}$ \\
\hline Alternaria & $5 \pm 0.5 \mathrm{a}$ & $30 \pm 0.8 \mathrm{~b}$ & $6 \pm 0.6 \mathrm{a}$ & $5 \pm 0.2 \mathrm{a}$ & $11.5 \pm 0.5 \mathrm{~A}$ \\
\hline Drying of buds & $65 \pm 3.1 \mathrm{a}$ & $79.58 \pm 1.7 \mathrm{a}$ & $50 \pm 1.6 \mathrm{a}$ & $83.33 \pm 10 \mathrm{~b}$ & $69.48 \pm 4.1 \mathrm{C}$ \\
\hline Powdery mildew & $27 \pm 1.3 \mathrm{a}$ & $40.83 \pm 3.1 \mathrm{~b}$ & $3.33 \pm 0.7 \mathrm{a}$ & $25 \pm 5 \mathrm{~b}$ & $24.04 \pm 2.5 \mathrm{~B}$ \\
\hline
\end{tabular}

Note. The mean values followed by the same lowercase letters in the rows (in the same site) and those followed by the same uppercase letters in the columns are not significantly different at the 5\% threshold according to Duncan's test.

\subsection{Average Severity (\%) of Diseases in the Two Sites}

Severities of anthracnose, alternaria, drying of buds and Pestalotia did not show statistical differences during the experimental conditions $(\mathrm{P}>0.05)$. In both sites the average severities of diseases was generally low. Anthracnose is the most severe disease followed by pestalotia leaf spot with mean severities of $18.5 \%$ and $15.5 \%$ respectively (Table 3).

Table 3. Severity of diseases in the two site by season (\%)

\begin{tabular}{|c|c|c|c|c|c|}
\hline \multirow{3}{*}{ Diseases } & \multicolumn{4}{|c|}{ Sites } & \multirow{3}{*}{ Mean } \\
\hline & \multicolumn{2}{|c|}{ Maroua } & \multicolumn{2}{|c|}{ Yagoua } & \\
\hline & Dry season & Rainy season & Dry season & Rainy season & \\
\hline Anthracnose & $14.34 \pm 2.6 \mathrm{a}$ & $20.55 \pm 6.3 \mathrm{a}$ & $17.85 \pm 7.2 \mathrm{a}$ & $21.47 \pm 5.5 \mathrm{a}$ & $18.55 \pm 5.4 \mathrm{C}$ \\
\hline Pestalotia & $19.2 \pm 2.4 \mathrm{a}$ & $16.24 \pm 3.8 \mathrm{a}$ & $18.76 \pm 5.7 \mathrm{~b}$ & $7.81 \pm 5.7 \mathrm{a}$ & $15.52 \pm 4.4 \mathrm{~B}$ \\
\hline Alternaria & $0.26 \pm 0.3 \mathrm{a}$ & $0.48 \pm 0.3 \mathrm{a}$ & $9.76 \pm 1.4 \mathrm{~b}$ & $0.06 \pm 0.1 \mathrm{a}$ & $2.64 \pm 0.5 \mathrm{~A}$ \\
\hline Dry of buds & $9.36 \pm 1.8 \mathrm{a}$ & $9.30 \pm 6.8 \mathrm{a}$ & $13.93 \pm 3.4 \mathrm{a}$ & $16.51 \pm 8.5 \mathrm{a}$ & $12.28 \pm 5.2 \mathrm{~B}$ \\
\hline Powdery mildew & $13.88 \pm 4.6 b$ & $1.35 \pm 0.9 \mathrm{a}$ & $1.64 \pm 0.2 \mathrm{a}$ & $1.30 \pm 1.6 \mathrm{a}$ & $4.54 \pm 1.8 \mathrm{~A}$ \\
\hline
\end{tabular}

Note. The mean values followed by the same lowercase letters in the rows (in the same site) and those followed by the same uppercase letters in the columns are not significantly different at the 5\% threshold according to Duncan's test.

\subsection{Prevalence of Fungal Diseases}

Surveys revealed the presence of all the diseases listed on the two varieties or accessions. However, the average incidence varies according to the varieties and disease. The highest average incidence values were recorded with anthracnose, pestalotia leaf spot and drying of buds, respectively $68.63,90.22$ and $72.04 \%$ on the red variety AB05-08 (Figure 5). 


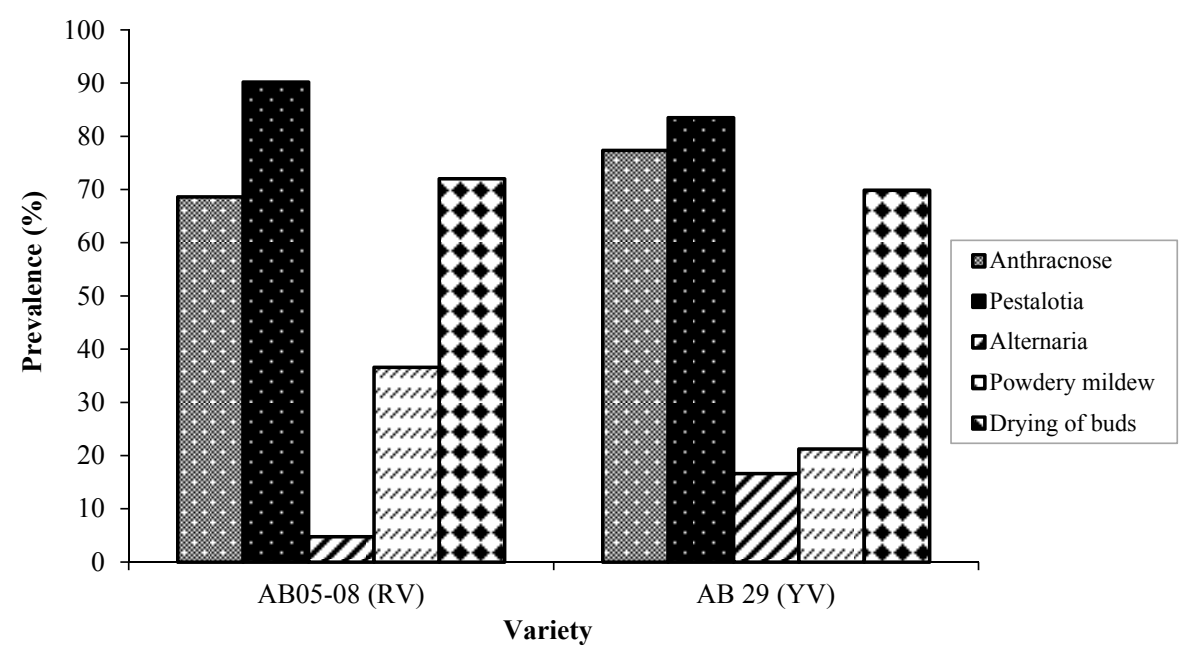

Figure 5. Prevalence of diseases in both varieties

\section{Discussion}

Several diseases such as anthracnose, pestalotia leaf spot, alternaria, powdery mildew, dry buds have been identified on cashew trees in the main cashew production region in Cameroon. All fungal diseases identified in the study areas were present during the two seasons. Similar results were found by different authors. Anthracnose (Colletotrichum gloeosporioides), pestalotia leaf spot (Pestalotia heterocornis) and powdery mildew (Ö̈dium anacardii) have also been identified among major diseases attacking cashew trees in Tanzania (NARI, 2009; Msoka, 2017), in Bénin (Afouda et al., 2013), in India (Khatoon et al., 2017) and Kenya (Menge \& Marthamakobe, 2016). Drying of the buds (Phomopsus anacardii) has also been reported in Mozambique (Uaciquete, 2013), in Ivory Coast (Nakpalo et al., 2017) and Burkina Faso (Wonni et al., 2017). Otherwise, this result underlines the major fungal diseases and their agents which can threaten the productivity of cashew in field if control measures are not undertaken to limit their spreading inside the country.

Anthracnose, pestalotia leaf spot and drying of buds have the highest incidence and severity. These diseases are therefore the most important in cashew orchards. Nakpalo et al. (2017), Wonni et al. (2017), Afouda et al. (2013), Araujo (2013), and Freire et al. (2002) have showed that anthracnose and pestalotia leaf spot are the most important diseases in all of the cashew orchards surveyed.

This study showed that almost all parts of the cashew plant are susceptible to pathogens attack. Colletotrichum is the most serious pathogen affecting almost many parts of the cashew plants. Colletotrichum sp. is are one of the most economically plant pathogens affecting a wide range of plant species (as cocoyam, cassava, mango). Uaciquete et al. (2013), and Lopez and Lucas (2010) have isolated Colletotrichum species from different organs of cashew.

Alternaria (Alternaria sp.) Is the disease least reported by the authors. However, Wonni et al. (2017) reported the attack on nuts and apple by Alternaria brassicae in Ivory Coast.

The results of the pathogenicity test are in agreement with those of Wonni et al. (2017) who after inoculation of young cashew trees containing 6-8 leaves by $P$. heterocornis, obtained symptoms similar to those of pestalotia 2-3 weeks later In addition, Uaciquete (2013) obtained similar results with the anthracnose pathogen (Colletotrichum gloeosporioides) in Mozambique on young leaves detached from the cashew tree. Khatoon et al. (2017) in India and Nakpalo et al. (2017) showed that the isolates were pathogenic on young plants aged six to seven months.

Curvularia sp. isolated from cashew foliar organs was recorded on leaves in Burkina Faso (Wonni et al., 2017). These fungi would be associated with cashew tree as saprophytic parasites but could appear pathogenic under favourable environmental conditions.

The average length of Alternaria sp. is from $18.07 \mu \mathrm{m}$ to $51.65 \mu \mathrm{m}$. The same lengths were reported by Bessadat (2014) in A. alternata $16.5 \mu \mathrm{m}$ to $56.5 \mu \mathrm{m}$. C. gloeosporioides had a length of $10.33 \mu \mathrm{m}$ to $18.07 \mu \mathrm{m}$ and a width of $2.58 \mu \mathrm{m}$ to $5.16 \mu \mathrm{m}$. This result is similar to that of Nakpalo et al. (2017) who obtained a length of $13.94 \mu \mathrm{m}$ and a width of $4.81 \mu \mathrm{m}$. In contrast, the conidia of Pestalotia heterocornis have a length of $15.49 \mu \mathrm{m}$ to $20.66 \mu \mathrm{m}$. This value was identical to that obtained by Nakpalo et al. (2017) who obtained an average length of $15.97 \mu \mathrm{m}$ but is far from the width they obtained, $5.96 \mu \mathrm{m}$ against $10.33-12.91 \mu \mathrm{m}$ obtained in this study. 
Alternaria and powdery mildew incidences were lower in all sites. This means that consequences are almost negligible in cashew. Our results are in contrast with thoses obtained by Ghini et al. (2011) which obtained incidence of 73 to $90.0 \%$ in Benin. However, precipitation, humidity and temperature are key factors for the fungus dispersal and infection. Despite the high rainfull $(1140.2$ and $901 \mathrm{~mm})$, severity was low in the two sites, because of the large canopy cannot favor dispersal of spores in the entire tree leaves.

The type of season is a very important parameter in the process of assessing evolutionary of a disease. Afouda et al. (2013) have shown that diseases such as anthracnose and dieback are lower in the dry season compared to the rainy season. All diseases inventoried except pestalotia leaf spot, had a high percentage in the rainy season and lower in the dry season. These differences may be due to the influence of rainfall, which is very favorable to the development of fungi and the drop of affected leaves (Nakpalo et al., 2017). This information provides the period of time when arrangements should be made to treat and prevent disease in the field.

The prevalence of anthracnose (77.37\%), pestalotia (90.22\%), and drying of buds $(72.04 \%)$ were very high in both varieties, and low for powdery mildew $(21.25 \%)$. The prevalence of these diseases on cashew orchards can partially justify the decrease of cashew yield. Soro (2011) had indicated that work on genotypes could facilitate the selection of cashew varieties. In addition, some varieties have a natural resistance which confers on them the capacity to overcome diseases during a certain age of their evolution.

Further investigations are needed to clarify impact of each disease in cashew orchards in Cameroon in order to improve yield.

Finally, the diversity of fungal diseases recorded on cashew in Cameroon is noteworthy. This may offer a potential for the development of sustainable control strategies against the economically important cashew diseases.

\section{Conckusion}

To our knowledge, this is the first study of inventory of cashew diseases in Cameroon. This study revealed that cashew fields in Cameroon are susceptible to diseases due to fungi. Among these fungal diseases, anthracnose (Colletotrichum gloeosporioides), pestalotia leaf spot (Pestalotia heterocornis) and drying of buds (Colletotrichum gloeosporioides + Phomopsus anacardii + Curvularia lunata) seem to be the most important in Cameroon cashew orchards. These findings create database for the morphological and molecular characterization of these pathogens and bases of integrate disease management approches.

\section{References}

Adeniyi, D. O., Animasaun, D. A., Adbulrahman, A. A., Olorunmaiye, K. S., Olahan, G. S., \& Adeji, O. A. (2019). Integrated system for cashew disease management and yield. Cameroon Journal of Experimental Biology, 13(1), 40-46. https://doi.org/10.4314/cajeb.v13i1.6

Adeniyi, D. O., Orisajo, S. B., Fademi, O. A., Adenuga, O. O., \& Dongo, L. N. (2011). Physiological studies of fungi complexes associated with cashew diseases. J. Agric. Biol. Sci., 6, 34-38.

Afouda, L. C. A., Zinsou, V., Balogoun, R. K., Onzo, A., \& Ahohuendo, B. C. (2013). Inventaire des agents pathogènes de l'anacardier (Anacardium occidentale L.) au Bénin. Bulletin de la Recherche Agronomique du Bénin, 73, 13-19.

Araújo, J. P. P. (2013). Agronegócio Caju: Práticas e inovações (p. 532). Brasília: Embrapa.

Assenga, B. B., Masawe, P. A., Tarimo, T. M., Kapinga, F., \& Mbega, E. R. (2020). Status of sucking insect pests in cashew growing locations of South and Central Zones, Tanzania. International Journal of Biosciences, 16(4), 34-45. https://doi.org/10.12692/ijb/16.4.34-45

Barnett, H. L., \& Hunter, B. B. (1987). Illustrated genera of imperfect fungi (4th ed.). MacMillan, New York, USA.

Bessadat, N. (2014). Isolement, identification et caractérisation des alternariasp. Responsables de la détérioration des plantes maraichères par des systèmes enzymatiques et moléculaires (p. 123, Thèse de doctorat PhD, Université d'Oran).

Cardoso, J. E., Bezerra, M. A., Viana, F. M. P., Sousa, T. R. M., Cysne, A. Q., \& Farias, F. C. (2009). Endophyte occurrence of Lasiodiplodia theobromae in cashew tissues and its transmission by vegetative propagules. Summa Phytopathologica, 35(4), 262-266. https://doi.org/10.1590/S0100-54052009000400002

Cooke, B. M. (2006). Disease assessment and yield loss. In B. M. Cooke, D. G. Jones, \& B. Kaye (Eds.), The epidemiology of plant diseases (pp. 43-80). Springer, Netherlands. https://doi.org/10.1007/1-4020-4581-6_2 
Diaz, B. M. T., Mbaro, T., Metais, A., Mendec, J., \& Couwenberghe, L. V. (2003). Inventaire, cartographie et plan simple de gestion de la plantation d'anacardiers de Mayo-Dadi, Province du Nord, Cameroun (p. 30). ENGREF/IRAD/CIRAD.

Didier, C. (2001). La culture de l'anacardier. Fruitrop, 81, 2-4.

Freire, F. C. O., Cardoso, J. E., dos Santos, A. A., \& Viana, F. M. P. (2002). Diseases of cashew nut plants (Anacardium occidentale L.) in Brazil. Crop Protection, 21, 489-49. https://doi.org/10.1016/S0261-2194 (01)00138-7

Ghini, R., Bettiol, W., \& Hamada, E. (2011). Diseases in tropical and plantation crops as affected by climate changes: Current knowledge and perspectives. Plant Pathol., 60(1), 122-132. https://doi.org/10.1111/ j.1365-3059.2010.02403.x

Grundon, N. J. (2000). The Australian cashew industry, an information system (pp. 1-182). Rural Industries Research Development Corporation (RIRDC), Australia.

INS. (2015). Annuaire statistique du Cameroun (pp. 232-255). Institute Statistique National au Cameroun, Younde.

Khatoon, A., Mohapatra, A., \& Kunja, B. S. (2017). Major diseases of cashew (Anacardium Occidentale L.) Caused by fungi and their control in Odisha, India. International Journal of Biosciences, 11(1), 68-74. https://doi.org/10.12692/ijb/11.1.68-74

Lautié, E., Dornier, M., De Souza, F., \& Reynes, M. (2001). Les produits de l'anacardier: Caractéristiques, voies de valorisation et marchés. Fruits, 56, 235-248. https://doi.org/10.1051/fruits:2001126

Lopez, A. M. Q., \& Lucas, J. A. (2010). Colletotrichum isolates related to anthracnose of cashew trees in Brazil: Morphological and molecular description using LSU rDNA sequences. Braz. Arch. Biol. Technol., 53, 741-752. https://doi.org/10.1590/S1516-89132010000400001

Menge, D., \& Marthamakobe. (2016). Biological control of cashew powdery mildew using Ampelomyces quisqualis. Journal of Biological Control, 30(4), 226-235. https://doi.org/10.18311/jbc/2016/15591

Mingue, S. (2019). Fiche Technique Anacarde: La culture de la noix de cajou. Agriculture au Cameroun.

Monteiro, F., Romeiras M. M., Figueiredo, A., Sebastiana, M. A., Balde, L. C., \& Batista, D. (2015). Tracking cashew economically important diseases in the West African region using metagenomics. Front. Plant Sci., 6, 2-6. https://doi.org/10.3389/fpls.2015.00482

Msoka, R., Kassim, N., Makule, E., \& Masawe, P. (2017). Physio-chemical properties of five cashew apple (Anacardium occidentale L.) varieties grown in different regions of Tanzania. International Journal of Biosciences, 11(5), 386-395. https://doi.org/10.12692/ijb/11.5.386-395

Nakpalo, S., Soro, S., Koné, T., Kouabenan, A., Koné, M., \& Koné, D. (2017). Parasitical fungi in Cashew (Anacardium occidentale L.) Orchard of Côte d'Ivoire. Plant Pathology Journal, 16(2), 82-88. https://doi.org/10.3923/ppj.2017.82.88

NARI. (2009). Diseases and insect pests of cashew (pp. 4-13, Technical Report). Naliendele Agricultural Institute, Naliendele, Tanzania.

Noiha, N. V., Zapfack, L., Awe, D. V., Witanou, N., Nyeck, B., Ngossomo, J. D., ... Tabue, M. R. B. (2017). Floristic structure and sequestration potential of cashew agroecosystems in Africa: A case study from Cameroon. Journal of Sustainable Forestry, 36(3), 277-288. https://doi.org/10.1080/10549811.2017. 1296776

Soro, D., Abreu, F. A. P., Assidjo, E., Yao, B., Dornier, M., \& Reynes, M. (2011). The cashew (Anacardium occidentale L.) industry in Ivory Coast-Analysis and prospects for développement. Fruits, 66, 4-9. https://doi.org/10.1051/fruits/2011031

Tandjiekpon, A., Lagbadohossou, A., Hinvi, J., \& Afonnon, E. (2003). La culture de l'anacardier au Bénin: Référentiel Technique (p. 86). INRAB-PADSE, Bénin.

Teixeira, L. M. S. (1988). Diseases. In V. P. M. S. Lima (Ed.), Cashew Tree Culture in North East of Brazil (pp. 157-179). BNB/ETENE, Brazil.

Uaciquete, A. (2013). Charactérization, epidemiology and control strategies for the anthracnose pathogène (Colletotrichum spp.) on cashew (Anacardium occidentale L.) in Mozambique (p. 85, PhD Thesis, University of Pretoria). 
Uaciquete, A., Korsten, L., \& Van der Waals, J. E. (2013). Epidemiology of cashew anthracnose (Colletotrichum gloeosporioides Penz.) in Mozambique. Crop Prot., 49, 66-72. https://doi.org/10.1016/j.cropro.2013.02.016

Viana, F. M. P., Cardoso, J. E., Suraiva, H. A. O. (2007). First report of a bacterial leaf and fruit spot of cashew nut (Anacardium occidentale) caused by Xanthomonas campestris pv. mangiferaeindicae in Brazil. Plant Dis., 91, 1361. https://doi.org/10.1094/PDIS-91-10-1361C

Wonni, I., Sereme, D., Ouedraogo, I., Kassankagno, A. I., Dao, I., Ouedraogo, L., \& Nacro, S. (2017). Diseases of cashew nut plants (Anacardium Occidentale L.) in Burkina Faso. Advances in Plants and Agriculture Research, 6(3),78-83. https://doi.org/10.15406/apar.2017.06.00216

\section{Copyrights}

Copyright for this article is retained by the author(s), with first publication rights granted to the journal.

This is an open-access article distributed under the terms and conditions of the Creative Commons Attribution license (http://creativecommons.org/licenses/by/4.0/). 